\title{
The Effect of Brown Seaweed and Cattle Manure Combinations on The Properties of Eisenia fetida's Organic Fertilizer
}

\author{
Mustafa Türkmen ${ }^{1, a, *}$, Köksal Duran ${ }^{2, b}$ \\ ${ }^{1}$ Department of Biology, Faculty of Science and Arts, Giresun University, 28200 Giresun, Turkey \\ *Corresponding author

\begin{tabular}{l|l}
\hline ART T C LE INFO & A B S T R A C T \\
\hline & In this study, the effect of brown seaweed (Cystoseira barbata) and cattle manure combinations
\end{tabular} \\ Research Article \\ were investigated as a worm food on the properties of Eisenia fetida worm manure. Seaweed \\ Cystoseira barbata were collected from the coast of Giresun, desalted and dried and then \\ ground. Cattle manure was obtained from cattle breeding dairy and had covered and fermented. \\ Received : 17/01/2021 \\ Accepted : 19/01/2021 \\ Food groups; $0 \%$ (control group); $5.45 \% ; 10.90 \% ; 21.81 \%$ and $43.63 \%$ of the algae were \\ prepared and containing three replicates were given to the worms. The experiment was \\ established in Giresun University Faculty of Science and Letters Biology laboratories according \\ to randomized plot design. The vermicompost groups were analyzed in terms of plant nutrients \\ and mineral levels. The obtained data showed that as the amount of algae increased in the \\ formula and vermicompost groups, the metal levels of $\mathrm{Zn}, \mathrm{Ni}, \mathrm{Fe}, \mathrm{Pb}, \mathrm{Cr}, \mathrm{Mn}, \mathrm{Mg}$ and $\mathrm{Cu}$ \\ Keywords: \\ Vermicompost \\ Brown Seaweed \\ Organic Fertilizer \\ decreased and carbon, $\mathrm{CaCO}_{3}, \mathrm{~N}, \mathrm{P}$ and $\mathrm{K}$ increased. This means that brown seaweed \\ Cystoseira barbata, which grows naturally on our coasts, can be used in the structure of \\ vermicompost.
} Eisenia fetida Mineral Levels

Türk Tarım - Gıda Bilim ve Teknoloji Dergisi, 9(6): 1070-1075, 2021

\section{Kahverengi Deniz Yosunu ve Çiftlik Gübresi Kombinasyonlarının Eisenia fetida Organik Gübresi Özelliklerine Etkisi}

\begin{tabular}{|c|c|}
\hline M A K A L E B İ L G İ S İ & Ö Z \\
\hline $\begin{array}{l}\text { Anahtar Kelimeler: } \\
\text { Vermikompost } \\
\text { Kahverengi Deniz Yosunu } \\
\text { Organik Gübre } \\
\text { Eisenia fetida } \\
\text { Mineral Düzeyleri }\end{array}$ & $\begin{array}{l}\text { Bu çalışmada, kahverengi deniz yosunu (Cystoseira barbata) ve sığır gübresi } \\
\text { kombinasyonlarının solucan maması olarak kullanılmasıyla, Eisenia fetida solucanı gübresinin } \\
\text { özelliklerine etkisi araştırılmıştır. Cystoseira barbata türü yosunlar Giresun sahillerinden } \\
\text { toplanmış, tuzu arındırıldıktan sonra kurutulmuş ve öğ̈̈tülmüştür. Sığır gübresi büyük baş } \\
\text { hayvan yetiştiriciliği yapan mandıralardan temin edilmiş ve fermente edilmiştir. Yosun ve } \\
\text { hayvan gübresinden elde edilen mama grupları; \%0; \%5,45; \% } 10,90 ; \% 21,81 \text { ve \% } 43,63 \\
\text { oranlarında yosun içerecek şekilde hazırlanmış ve üçer tekerrür olarak solucanlara verilmiştir. } \\
\text { Deneme tesadüf parselleri deneme desenine göre kurulmuştur. Elde edilen solucan gübresi } \\
\text { (vermikompost) gruplarının bitki besin elementleri ve mineral düzeyleri açısından analizler } \\
\text { yapılmıştır. Elde edilen veriler mama ve vermikompost gruplarındaki yosun miktarı arttıkça Zn, } \\
\text { Ni, Fe, Pb, Cr, Mn, Mg ve Cu metal seviyelerinin düştüğünü, organik madde, karbon, kireç, N, } \\
\mathrm{P} \text { ve K gibi bitki besleyici maddelerin oranlarının arttığını göstermiştir. Bu durum sahillerimizde } \\
\text { doğal olarak yetişen kahverengi deniz yosunu Cystoseira barbata'nın vermikompostun } \\
\text { yapısında kullanılabileceğini ifade etmektedir. }\end{array}$ \\
\hline
\end{tabular}




\section{Introduction}

Vermicomposting is a non-thermophilic biological process in which the organic material is transformed by worms into a peat fertilizer with high porosity, aeration, drainage, water holding capacity and rich microbial activities (Edwards, 1998; Atiyeh et al., 2000a; Arancon et al., 2004). Vermiculture is a cost-effective tool for environmentally friendly waste management (Banu et al., 2001; Asha et al., 2008). Studies show that worms contain substances with strong antimicrobial properties and that these substances are the most important elements of the worms' immune system. By using these substances, which worms use to protect themselves from pathogenic microorganisms, it may be possible to neutralize pathogens that cause great damage to cultivated plants and cause intense chemical use. In studies on this subject, it has been determined that when the liquid form of vermicompost is sprayed on the plants, insects do not approach the plants and the plants become resistant to diseases (Edwards, 1998; Atiyeh et al., 2000b; Arancon, 2004).

The positive effects of vermicomposting on $\mathrm{pH}$, electrical conductivity (EC), $\mathrm{C}$ : $\mathrm{N}$ ratio and other nutrients have been documented. Worm activity reduced $\mathrm{pH}$ and $\mathrm{C}$ : $\mathrm{N}$ ratio in fertilizer (Gandhi et al., 1997; Atiyeh et al., 2000a). Studies have shown that vermicompost has lower $\mathrm{pH}$, EC, organic carbon (OC) compared to the main material (Nardi et al., 1983; Albanell et al., 1988; Mitchell 1997), and has higher amounts of nitrogen and potassium total phosphorus and micronutrients (Hashemimajd et al., 2004). Vermicompost contains higher nutrient concentrations but produces more salinity than composts. EC indicates the salinity of the organic change. Compared to the main material used, vermicomposts have less soluble salt and greater cation exchange capacity (Holtzclaw and Sposito, 1979; Albanell et al., 1988).

Due to their different properties, marine algae have become the center of attention with many researches (Türkmen and Kütük, 2017; Dyo et al., 2018; Lauritano et al., 2020; Riccio and Lauritano 2020; Rosales-Mendoza et al., 2020; Silva et al., 2020; Türkmen and Akyurt, 2021; Türkmen and Aydın, 2021). Vermicomposts can significantly affect the growth and productivity of plants due to their micro and macro elements, vitamins, enzymes and hormones (Kale et al., 1992; Kalembasa, 1996; Edwards, 1998; Sinha et al., 2009). Vermicomposts have a special structure that provides strong microbial activity (Shi-Wei and Fu-Zhen, 1991). Mucus expelled from the worm digestive tract stimulates antagonism and competition between various microbial populations, accelerating the production of some antibiotics and hormone-like biochemicals and plant growth (Edwards and Bohlen, 1996). The aim of this study is to investigate the effects of Eisenia fetida worm fertilizer obtained by using brown seaweed (Cystoseira barbata) and cattle manure combinations as worm feed.

\section{Material and Methods}

The cattle manure used in this study was obtained from a cattle breeding barn in a village in Giresun Province. In this study, brown seaweed (Cystoseira barbata) used as research material was collected from the natural environment of Giresun province and district coasts (Piraziz; 40 57' 12' N $38^{\circ} 07^{\prime} 56^{\prime \prime} \mathrm{E}$, Bulancak; $40^{\circ} 56^{\prime} 36^{\prime \prime} \mathrm{N}$ $38^{\circ} 15^{\prime} 02^{\prime \prime} \mathrm{E}$, Giresun; $40^{\circ} 54^{\prime} 57^{\prime \prime} \mathrm{N} 38^{\circ} 25^{\prime} 05^{\prime \prime} \mathrm{E}$, Tirebolu; $41^{\circ} 00^{\prime} 39^{\prime \prime} \mathrm{N} 38^{\circ} 51^{\prime} 56^{\prime \prime} \mathrm{E}$, Eynesil; $41^{\circ} 03^{\prime} 58^{\prime \prime} \mathrm{N} 39^{\circ} 08^{\prime} 26^{\prime \prime}$ E). Cystoseira barbata type of algae was detached from the rocks they held on and placed in nets and the sea water was awaited to escape. The algae brought to the laboratory environment were washed with tap water and other algae species, mussels and other undesirable substances were removed. These cleaned algae were spread and dried, and the powder was cut into 0.5 to $1.0 \mathrm{~cm}$ size with the help of a grinding tool (Türkmen and $\mathrm{Su}, 2019$ ). Then, the mixtures in Table 1 were prepared from chopped seaweed and cattle manure, and food groups were formed by fermentation. After the initial samples were taken from the prepared food groups for analysis, each group was distributed in three replicates of $1500 \mathrm{~g}$ into the containers.

The average weight of Eisenia fetida worms in containers with food groups was calculated and left as 45 $\mathrm{g}$ per container $(0.225 \mathrm{~g} / \mathrm{worm}$ and an average of 200 pieces / container). Trial containers were placed in the laboratory environment according to the order of trial random plots and temperature and humidity controls were carried out every two days until the worms consumed the food. One month after the trial was established, it was observed that the worms consumed the formula and the trial was terminated. The vermicompost samples in the containers were dried separately, sieved and prepared for analysis after the worms were removed. The methods of humic fulvic acid, $\mathrm{N}, \mathrm{CaCO}_{3}$, organic $\mathrm{C}, \mathrm{P}, \mathrm{Ca}, \mathrm{Cu}, \mathrm{K}, \mathrm{Mg}$, $\mathrm{Mn}, \mathrm{Zn}, \mathrm{Ni}, \mathrm{Fe}, \mathrm{As}, \mathrm{Pb}, \mathrm{Cr}, \mathrm{Na}, \mathrm{pH}, \mathrm{EC}$ and organic matter analyses were presented in Table 2 (Kacar., 2016).

\section{Results and Discussion}

$1500 \mathrm{~g}$ of food and 200 worms (45 g) were left in each container, after 30 days it was observed that the worms consumed about their own weight daily. During the formation of vermicompost, the temperature and humidity of the environment were kept at optimum levels of $20-25^{\circ} \mathrm{C}$ and $60-70 \%$ humidity. Studies have stated that these values are the most suitable values for the activities of the worm (Sharma et al., 2005). EC and pH values of trial groups were given in Table 3 according to the groups.

The $\mathrm{pH}$ values increased as the amount of algae in the groups increased, except for the third group of food and the second group of vermicompost, but it was lower in vermicompost compared to the food groups. However, it is seen that the $\mathrm{pH}$ values of all food and vermicompost groups are neutral. It is considered that the lower EC values in the vermicompost groups compared to the food groups may be due to the lower amount of soluble salt in vermicompost. On the other hand, it is seen that all groups are slightly salty. Plant nutritional values of prepared food groups and obtained vermicompost groups are given in Table 4. The differences between the plant nutrition values of worm food and vermicompost groups were statistically significant $(\mathrm{P}<0.05)$. Organic matter and organic carbon were highest in V5 group, $\mathrm{P}$ and $\mathrm{K}$ WF3 group, $\mathrm{CaCO}_{3}$ WF5 group, nitrogen V4 group and humic fulvic acid WF1 group. As the amount of algae in the food and 
vermicompost groups increased, the amount of organic matter and $\mathrm{CaCO}_{3}$ increased, and no significant change was observed in carbon, nitrogen and potassium levels depending on the amount of algae. Nitrogen is one of the most essential nutrients that stimulate the formation of leaves and stems in plants. It affects important physiological developments in the plant body, product amount and product quality (Çepel, 1988). On the other hand, total humic fulvic acid amounts decreased except the fourth groups of food and vermicompost. This shows that there is a higher amount of humic-fulvic acid in composted animal manure compared to algae. While the total amount of phosphorus showed a change independent of the algae ratio in the food groups, it decreased in the vermicompost groups with the increase of algae, except for the fourth group.

The mineral substance levels of the food and vermicompost groups are presented in Table 5. The differences between the mineral substance levels of the food and vermicompost groups were statistically significant $(\mathrm{P}<0.05)$. As can be seen from the table, heavy metals such as $\mathrm{Zn}, \mathrm{Ni}, \mathrm{Fe}, \mathrm{Pb}, \mathrm{Cr}, \mathrm{Mn}, \mathrm{Mg}$ and $\mathrm{Cu}$ reached the highest levels in the food control group and their levels decreased as the amount of algae in the groups increased. This implies that these metals are at higher levels in animal manure than brown seaweed and that heavy metal levels decrease due to the increase in algae content. The group with the highest calcium content is the fifth group of vermicompost, that is, the group with the highest amount of algae. The group with the highest sodium content was the fourth group of vermicompost. This shows that $\mathrm{Na}$ and $\mathrm{Ca}$ elements are higher in algae material. In this case, it can be said that worms accumulate these metals in their bodies (bioremediation) during vermicomposting and cause a decrease in heavy metal levels in vermicompost.

Considering the analysis results, it was seen that the total amount of humic-fulvic acid decreased as the amount of algae in food mixtures increased and vermicomposting. The amount of organic matter increased due to the increase in the rate of algae, and after vermicomposting, it also increased compared to the food groups. It was observed that the amount of organic carbon was statistically insignificant in the food groups except for the first and third groups, but increased with the increase of algae in the vermicompost groups. The amount of $\mathrm{CaCO}_{3}$ was statistically different in the food groups except for the second and fifth groups, but in the vermicompost groups, it increased with the increase in the amount of algae except the third group. It was observed that the total $\mathrm{N}$ amounts were statistically insignificant in the food and vermicompost groups. It was observed that the amount of phosphorus in the food groups showed an independent variation from the amount of algae, whereas in the vermicompost groups, it was statistically no different except for the fifth group. Again, the amount of potassium varied independently from the amount of algae in the food groups, but it was observed that the amount of algae increased in the vermicompost groups except for the third group.

Table 1. Mixing ratios of food groups

\begin{tabular}{|c|c|c|}
\hline Groups & Mixes & Algae Ratio (\%) \\
\hline WF1 & $5.500 \mathrm{~g}$ Manure & $0 \%$ \\
\hline WF2 & $5.200 \mathrm{~g}$ Manure $+300 \mathrm{~g}$ Algae & $5.45 \%$ \\
\hline WF3 & $4.900 \mathrm{~g}$ Manure + $600 \mathrm{~g}$ Algae & $10.90 \%$ \\
\hline WF4 & $4.300 \mathrm{~g}$ Manure + $1.200 \mathrm{~g}$ Algae & $21.81 \%$ \\
\hline WF5 & $3.100 \mathrm{~g}$ Manure + $2.400 \mathrm{~g}$ Algae & $43.63 \%$ \\
\hline
\end{tabular}

WF: Worm Food

Table 2. The Parameters, Methods and Units analyzed in Worm Food and Vermicompost

\begin{tabular}{c|cc}
\hline Parameters & Units & Methods \\
\hline Humic-Fulvic Acid & $\%$ & TSE 5869 ISO 5073 \\
$\mathrm{CaCO}_{3}$ & $\%$ & Scheibler Kalsimetrik \\
$\mathrm{pH}$ & & TS ISO 10390 \\
$\mathrm{EC}$ & $\mathrm{dS} / \mathrm{m}$ & TS ISO 11265 \\
$\mathrm{N}$ and C & $\%$ & Elemental Analyzer \\
$\mathrm{Mn}, \mathrm{Fe}, \mathrm{Ni}, \mathrm{Cu}, \mathrm{Zn}, \mathrm{As}, \mathrm{Pb}, \mathrm{Cr}, \mathrm{K}, \mathrm{P}, \mathrm{Ca}, \mathrm{Na}, \mathrm{Mg}$ & $\mathrm{ppm}$ & ICP-MS \\
Organic Matter & $\%$ & TS8336 (Walkley-Black) \\
\hline
\end{tabular}

Table 3. pH and Electrical Conductivity Values of Food and Vermicompost Groups

\begin{tabular}{l|cc}
\hline Groups & $\mathrm{pH}$ & $\mathrm{EC}(\mathrm{dS} / \mathrm{m})$ \\
\hline WF1 & $7.0 \pm 0.02$ & $4.65 \pm 0.08$ \\
WF2 & $7.1 \pm 0.02$ & $3.96 \pm 0.02$ \\
WF3 & $6.9 \pm 0.02$ & $5.05 \pm 0.05$ \\
WF4 & $7.1 \pm 0.02$ & $5.65 \pm 0.02$ \\
WF5 & $7.2 \pm 0.02$ & $4.95 \pm 0.11$ \\
V1 & $6.8 \pm 0.02$ & $4.80 \pm 0.05$ \\
V2 & $6.7 \pm 0.02$ & $5.30 \pm 0.05$ \\
V3 & $6.8 \pm 0.02$ & $5.56 \pm 0.01$ \\
V4 & $6.9 \pm 0.02$ & $5.45 \pm 0.05$ \\
V5 & $7.1 \pm 0.02$ & $5.72 \pm 0.07$ \\
\hline
\end{tabular}

WF: Worm Food, V: Vermicompost 
Table 4. Plant Nutrition Values of Worm Food and Vermicompost Groups

\begin{tabular}{c|ccccccc}
\hline Grp & Humic Fulvic Acid (\%) & Organic Matter (\%) & Organic C (\%) & $\mathrm{CaCO}_{3}(\%)$ & $\mathrm{N}(\%)$ & $\mathrm{P}(\mathrm{ppm})$ & $\mathrm{K}(\mathrm{ppm})$ \\
\hline WF1 & $78.2 \pm 0.57^{\mathrm{h}}$ & $32.2 \pm 0.23^{\mathrm{b}}$ & $20.3 \pm 0.54^{\mathrm{b}}$ & $1.70 \pm 0^{\mathrm{a}}$ & $\underline{0.02 \pm 0^{\mathrm{a}}}$ & $1455 \pm 255^{\mathrm{bc}} 5048 \pm 133^{\mathrm{bc}}$ \\
WF2 & $66.2 \pm 0.05^{\mathrm{f}}$ & $\underline{26.8 \pm 0.77^{\mathrm{a}}}$ & $19.9 \pm 0.06^{\mathrm{b}}$ & $3.40 \pm 0^{\mathrm{b}}$ & $0.03 \pm 0^{\mathrm{a}}$ & $1057 \pm 136^{\mathrm{bc}}$ & $3370 \pm 526^{\mathrm{a}}$ \\
WF3 & $62.2 \pm 0.57^{\mathrm{e}}$ & $30.9 \pm 0.83^{\mathrm{b}}$ & $21.3 \pm 0.60^{\mathrm{bc}}$ & $1.70 \pm 0^{\mathrm{a}}$ & $0.02^{\mathrm{a}}$ & $1671 \pm 35^{\mathrm{c}}$ & $5927 \pm 175^{\mathrm{c}}$ \\
WF4 & $65.7 \pm 0.55^{\mathrm{ef}}$ & $33.3 \pm 0.57^{\mathrm{b}}$ & $23.7 \pm 0.11^{\mathrm{d}}$ & $1.70 \pm 0^{\mathrm{a}}$ & $0.02^{\mathrm{a}} \pm 0^{\mathrm{a}}$ & $1548 \pm 205^{\mathrm{bc}}$ & $5767 \pm 411^{\mathrm{c}}$ \\
WF5 & $55.3 \pm 1.15^{\mathrm{d}}$ & $44.3 \pm 0.74^{\mathrm{e}}$ & $33.8 \pm 0.34^{\mathrm{f}}$ & $7.93 \pm 0^{\mathrm{d}}$ & $0.04 \pm 0.02^{\mathrm{a}}$ & $973 \pm 144^{\mathrm{b}}$ & $5358 \pm 984^{\mathrm{bc}}$ \\
V1 & $73.1 \pm 1.57^{\mathrm{g}}$ & $38.6 \pm 0.67^{\mathrm{c}}$ & $26.3 \pm 0.57^{\mathrm{e}}$ & $2.55 \pm 0^{\mathrm{b}}$ & $0.04 \pm 0^{\mathrm{a}}$ & $1191 \pm 31^{\mathrm{bc}}$ & $3618 \pm 246^{\mathrm{b}}$ \\
V2 & $54.4 \pm 1.57^{\mathrm{d}}$ & $41.6 \pm 0.69^{\mathrm{de}}$ & $22.2 \pm 0.63^{\mathrm{cd}}$ & $3.40 \pm 0^{\mathrm{b}}$ & $0.02^{\mathrm{a}} \pm 0^{\mathrm{a}}$ & $1158 \pm 48^{\mathrm{bc}}$ & $4068 \pm 142^{\mathrm{bc}}$ \\
V3 & $15.6 \pm 0.48^{\mathrm{a}}$ & $41.1 \pm 1.01^{\mathrm{cd}}$ & $19.4 \pm 0.34^{\mathrm{a}}$ & $2.55 \pm 0^{\mathrm{b}}$ & $0.02^{\mathrm{a}}$ & $1008 \pm 25^{\mathrm{b}}$ & $3539 \pm 153^{\mathrm{b}}$ \\
V4 & $45.3 \pm 1.03^{\mathrm{c}}$ & $42.8 \pm 0.91^{\mathrm{de}}$ & $23.7 \pm 0.11^{\mathrm{d}}$ & $5.10 \pm 0^{\mathrm{c}}$ & $0.04 \pm 0.01^{\mathrm{a}}$ & $1199 \pm 20^{\mathrm{bc}}$ & $4996 \pm 7.0^{\mathrm{bc}}$ \\
V5 & $23.3 \pm 0.64^{\mathrm{b}}$ & $44.4 \pm 0.87^{\mathrm{e}}$ & $23.7 \pm 0.36^{\mathrm{d}}$ & $5.38 \pm 0.56^{\mathrm{c}}$ & $0.03 \pm 0.01^{\mathrm{a}}$ & $\underline{894 \pm 28^{\mathrm{a}}}$ & $5693 \pm 33^{\mathrm{c}}$ \\
\hline
\end{tabular}

*WF: Worm Food, V: Vermicompost, 1: Control, 2: 5.45 Algae \%, 3: $10.90 \%$ Algae, 4: $21.81 \%$ Algae, 5: $43.63 \%$ Algae, **Vertically, different letters show statistically significant differences between groups $(\mathrm{P}<0.05)$.

Table 5. Mineral Matter Levels of Food and Vermicompost Groups (ppm)

\begin{tabular}{|c|c|c|c|c|c|c|}
\hline Grp & $\mathrm{Zn}$ & $\mathrm{Ni}$ & $\mathrm{Fe}$ & As & $\mathrm{Pb}$ & $\mathrm{Cr}$ \\
\hline WF1 & $68.2 \pm 0.95^{\mathrm{d}}$ & $10.9 \pm 1.28^{c}$ & $15371 \pm 429^{d}$ & $5.38 \pm 0.84^{\text {bcde }}$ & $5.76 \pm 0.28^{\mathrm{d}}$ & $14.2 \pm 0.41^{\mathrm{d}}$ \\
\hline WF2 & $47.8 \pm 6.82^{\mathrm{abc}}$ & $5.28 \pm 1.17^{\mathrm{ab}}$ & $8906 \pm 1414^{\mathrm{bc}}$ & $3.85 \pm 0.87^{\mathrm{abcd}}$ & $5.27 \pm 0.97^{\mathrm{bcd}}$ & $3.70 \pm 1.56^{\mathrm{abc}}$ \\
\hline WF3 & $63.1 \pm 1.71^{\mathrm{cd}}$ & $8.80 \pm 0.53^{\mathrm{bc}}$ & $12775 \pm 260^{\mathrm{cd}}$ & $4.78 \pm 0.18^{\mathrm{abcde}}$ & $4.96 \pm 0.17^{\mathrm{bcd}}$ & $10.4 \pm 0.73^{\mathrm{d}}$ \\
\hline WF4 & $61.5 \pm 5.68^{\mathrm{bcd}}$ & $7.74 \pm 0.69^{\mathrm{bc}}$ & $12864 \pm 1108^{\mathrm{cd}}$ & $6.51 \pm 0.83^{\mathrm{de}}$ & $5.43 \pm 0.48^{\mathrm{cd}}$ & $8.3 \pm 1.58^{\mathrm{bcd}}$ \\
\hline WF5 & $48.9 \pm 7.31^{\mathrm{abc}}$ & $5.48 \pm 1.30^{\mathrm{ab}}$ & $8716 \pm 1789^{\mathrm{bc}}$ & $6.16 \pm 0.91^{\mathrm{cde}}$ & $4.41 \pm 0.79^{a b c d}$ & $9.22 \pm 3.27^{\mathrm{cd}}$ \\
\hline V1 & $46.2 \pm 1.84^{\mathrm{abc}}$ & $3.81 \pm 0.20^{\mathrm{a}}$ & $6576 \pm 316^{\mathrm{ab}}$ & $2.01 \pm 0.17^{\mathrm{a}}$ & $3.65 \pm 0.12^{\mathrm{abcd}}$ & $2.61 \pm 0.22^{\mathrm{ab}}$ \\
\hline $\mathrm{V} 2$ & $46.6 \pm 1.79 \mathrm{abc}$ & $3.68 \pm 0.63^{\mathrm{a}}$ & $5795 \pm 231^{\mathrm{ab}}$ & $3.19 \pm 0.68^{\mathrm{abcd}}$ & $3.33 \pm 0.05^{\mathrm{abc}}$ & $2.11 \pm 0.02^{\mathrm{ab}}$ \\
\hline V3 & $39.5 \pm 0.30^{\mathrm{a}}$ & $3.28 \pm 0.36^{\mathrm{a}}$ & $5079 \pm 399^{a b}$ & $2.42 \pm 0.02^{\mathrm{ab}}$ & $3.33 \pm 0.64^{\mathrm{abc}}$ & $2.30 \pm 0.21^{\mathrm{ab}}$ \\
\hline V4 & $45.9 \pm 1.55^{\mathrm{abc}}$ & $3.45 \pm 0.26^{\mathrm{a}}$ & $5047 \pm 158^{\mathrm{ab}}$ & $3.75 \pm 0.10^{\mathrm{abcd}}$ & $2.87 \pm 0.07^{\mathrm{ab}}$ & $2.58 \pm 0.22^{\mathrm{ab}}$ \\
\hline V5 & $42.8 \pm 0.36^{\mathrm{abc}}$ & $2.48 \pm 0.12^{\mathrm{a}}$ & $3293 \pm 177^{\mathrm{a}}$ & $6.97 \pm 0.54^{\mathrm{e}}$ & $2.08 \pm 0.02^{\mathrm{a}}$ & $1.88 \pm 0.22^{\mathrm{a}}$ \\
\hline Grp & $\mathrm{Mn}$ & $\mathrm{Ca}$ & $\mathrm{Mg}$ & $\mathrm{Na}$ & $\mathrm{Cu}$ & \\
\hline WF1 & $468 \pm 28.7^{\mathrm{e}}$ & $9461 \pm 226^{\text {bc }}$ & $4264 \pm 69,0^{c}$ & $736 \pm 71,9^{b}$ & $28,4 \pm 2,30^{\mathrm{d}}$ & \\
\hline WF2 & $293 \pm 47.9^{\mathrm{bcd}}$ & $6003 \pm 539^{a}$ & $2719 \pm 371^{\mathrm{ab}}$ & $732 \pm 91,5^{b}$ & $13,0 \pm 2,37^{\mathrm{abc}}$ & \\
\hline WF3 & $364 \pm 11.4^{\mathrm{cde}}$ & $9366 \pm 205^{\mathrm{bc}}$ & $4199 \pm 112^{\mathrm{c}}$ & $825 \pm 46,7^{b}$ & $18,1 \pm 1,02^{\mathrm{c}}$ & \\
\hline WF4 & $401 \pm 21.8^{\mathrm{de}}$ & $10398 \pm 519^{b c}$ & $4083 \pm 126^{c}$ & $673 \pm 137^{b}$ & $17,1 \pm 0,63^{\mathrm{bc}}$ & \\
\hline WF5 & $289 \pm 50.3^{\mathrm{bcd}}$ & $13570 \pm 1541^{d}$ & $3398 \pm 561^{b c}$ & $14,3 \pm 2,37^{a}$ & $13,4 \pm 2,43^{\mathrm{abc}}$ & \\
\hline $\mathrm{V} 1$ & $284 \pm 14.7^{\text {bcd }}$ & $6086 \pm 212^{\mathrm{a}}$ & $2397 \pm 91,9^{\mathrm{ab}}$ & $263 \pm 27,9^{\mathrm{a}}$ & $11,5 \pm 0,60^{\mathrm{abc}}$ & \\
\hline $\mathrm{V} 2$ & $272 \pm 4.32^{\mathrm{abc}}$ & $8136 \pm 230^{\mathrm{ab}}$ & $2418 \pm 11,7^{\mathrm{ab}}$ & $121 \pm 22,5^{\mathrm{a}}$ & $10,1 \pm 0,73^{\mathrm{a}}$ & \\
\hline V3 & $229 \pm 7.81^{\mathrm{ab}}$ & $8183 \pm 225^{\mathrm{ab}}$ & $2201 \pm 73,1^{\mathrm{a}}$ & $828 \pm 12,6^{b}$ & $8,30 \pm 0,31^{\mathrm{a}}$ & \\
\hline V4 & $241 \pm 3.11^{\mathrm{abc}}$ & $11601 \pm 147^{\mathrm{cd}}$ & $2664 \pm 35,4^{\mathrm{ab}}$ & $847 \pm 27,0^{b}$ & $10,3 \pm 0,40^{\mathrm{ab}}$ & \\
\hline V5 & $155 \pm 1.43^{\mathrm{a}}$ & $17051 \pm 300^{\mathrm{e}}$ & $2791 \pm 28,1^{\mathrm{ab}}$ & $637 \pm 51,6^{b}$ & $7,37 \pm 0,49^{\mathrm{a}}$ & \\
\hline
\end{tabular}

${ }^{*}$ Vertically, different letters show statistically significant differences between groups $(\mathrm{P}<0.05)$.

In the study comparing traditional compost and vermicompost in the growth and yield of tomatoes, some differences in plant growth were noted. It has been stated that the difference between compost and vermicompost applications in plant development is due to the fact that most of the usable $\mathrm{N}$ form that the plant takes is released in the form of $\mathrm{NO}_{3}-\mathrm{N}$ in vermicompost and in the form of $\mathrm{NH}_{4}-\mathrm{N}$ in compost, which is due to the fundamental difference between the vermicomposting process using quite different microbial composts and composting (Atiyeh et al., 2000c). In the same study, it was stated that tomato plant showed more improvement in vermicompost application. In other studies, it has been reported that the increase in the total $\mathrm{N}$ content of soils as a result of applying organic wastes to the soil by vermicomposting is higher than the application of these organic wastes to soils without vermicomposting (Kaushik and Garg, 2003; Arancon et al., 2004). In a study conducted by Pattnaik and Reddy (2012), it was found that $\mathrm{Pb}, \mathrm{Zn}, \mathrm{Cd}, \mathrm{Cu}$, and $\mathrm{Mn}$ heavy metals were significantly removed by vermicomposting. In a study investigating the removal of $\mathrm{Pb}, \mathrm{Ni}, \mathrm{Al}$ heavy metals from industrial sludge by vermicomposting method, it was concluded that the removal of these metals was $97 \%, 86 \%, 72 \%$, respectively (Shaymaa et al., 2010).

During vermicomposting, it forms complexes containing heavy metals, humic acids and other polymerized organic fractions, resulting in lower levels of heavy metals that are phytotoxic to plants (Dominguez and Edwards, 2004). Higher quality fruits and vegetables with less heavy metal or nitrate content were produced in the soil to which vermicompost was added (Kolodziej and Kostecka, 1994). According to the data obtained in the study, it was determined that heavy metal levels in both food mixtures and vermicompost groups were well below the organic fertilizer heavy metal limits reported by the Ministry of Agriculture. This shows that using vermicomposts in agricultural areas can prevent heavy metal pollution.

In terms of plant nutrients, it is concluded that all vermicompost groups in this study where brown seaweed $C$. barbata was used in the production of worm food will be beneficial for the plant, while the vermicompost groups that should be used according to the characteristics of the soil where the plant will be grown will be different. It would be more appropriate to use non-moss control group in soils with low total humic-fulvic acid and P amount. On the other hand, 
it would be more beneficial to use the fifth group of vermicompost group, which has the highest (43.63\%) algae amount in soils with low organic matter, organic $\mathrm{C}, \mathrm{K}$ and $\mathrm{CaCO}_{3}$. It is recommended to use the fourth group of vermicompost group containing $21.81 \%$ moss in soils with low $\mathrm{N}$ ratio. In order to obtain more accurate results, it will be possible to perform bioassays using vermicompost groups obtained with a specific plant species to determine which group supports plant growth more.

\section{Acknowledgements}

Thanks to Giresun University for its financial support (Project No: FEN-BAP-A-230218-31).

\section{References}

Albanell E, Plaixats J, Cabrero T. 1988. Chemical changes during vermicomposting (Eisenia fetida) of sheep manure mixed with cotton industrial wastes. Biology and Fertility of Soils. 6: 266-269. https://doi.org/10.1007/BF00260823.

Arancon NQ, Edwards CA, Bierman P, Welch C, Metzger JD. 2004. Influences of vermicomposts on field strawberries: 1. Effects on growth and yields. Bioresource Technology. 93: 145-153. doi:10.1016/j.biortech.2003.10.014.

Asha A, Tripathi AK, Soni P. 2008. Vermicomposting: A Better Option for Organic Solid Waste Management. Journal of Human Ecology. 24:59-64. doi: 10.1080/09709274.2008. 11906100.

Atiyeh RM, Dominguez J, Subler S, Edwards CA. 2000a. Changes in biochemical properties of cow manure during processing by earthworms (Eisenia andrei, Bouché) and the effects on seedling growth. Pedobiologia. 44: 709-724. https://doi.org/10.1078/S0031-4056(04)70084-0.

Atiyeh RM, Subler S, Edwards CA, Bachman G, Metzger JD, Shuster W. 2000b. Effects of vermicomposts and composts on plant growth in horticulture container media and soil. Pedobiologia. 44: 579-590. https://doi.org/10.1078/S00314056(04)70073-6.

Atiyeh RM, Arancon NQ, Edwards CA, Metzger JD. 2000c. Influence of earthworm- processed pig manure on the growth and yield of green house tomatoes. Bioresource Technology. 75:175-180. https://doi.org/10.1016/S0960-8524(00)00064$\mathrm{X}$.

Banu JR, Logakanthi S, Vijayalakshmi GS. 2001. Biomanagement of paper mill sludge using an indigenous (Lampito mauritii) and two exotic (Eudrilus eugineae and Eisenia fetida) earthworms. Journal of Environmental Biology. 22: 181-185.

Çepel N. 1988. Orman Toraklarının Karakteristikleri, Toprakların Oluşumu, Özellikleri ve Ekolojik Bakımdan Değerlendirilmesi. İstanbul Üniversitesi Orman Fakültesi Yayınlar1, 389; 188-195

Dominguez J, Edwards CA. 2004. Vermicomposting organic wastes: A review. In: Shakir Hanna SH, Mikhail WZA, editors. Soil Zoology for sustainable Development in the 21 st century. 369-395.

Dyo YM, Purton S. 2018. The algal chloroplast as a synthetic biology platform for production of therapeutic proteins. Microbiology. 164: 113-121. doi 10.1099/mic.0.000599.

Edwards CA. 1998. The use of earthworms in the breakdown and management of organic wastes. In: Edwards CA, editor. Earthworm Ecology. Boca Raton: CRC Press. 327-354.

Edwards CA, Bohlen PJ. 1996. Biology and Ecology of earthworms. London: Chapman and Hall; p. 426.

Gandhi M, Sangwan V, Kapoor KK, Dilbaghi N. 1997. Composting of household wastes with and without earthworms. Environment and Ecology. 15: 432-434.
Hashemimajd K, Kalbasi M, Golchin A, Shariatmadari H. 2004. Comparison of vermicompost and composts as potting media for growth of tomatoes. Journal of Plant Nutrition. 27: 11071123. https://doi.org/10.1081/PLN-120037538.

Holtzclaw KM, Sposito G. 1979. Analytical properties of the soluble metal-complexing fractions in sludge-soil mixtures. IV. Determination of carboxyl groups in fulvic acid. Soil Science Society of America Journal. 43: 318-323. https://doi.org/10.2136/sssaj1979.03615995004300020016x.

Kacar B. 2016. Fiziksel ve Kimyasal Toprak Analizleri: Bitki, Toprak ve Gübre Analizleri3. Nobel Akademik Yayıncılık. S. 632.

Kale RD, Mallesh BC, Bano K, Bagyaray DJ. 1992. Influence of vermicompost application on the available macronutrients and selected microbial populations in paddy field. Soil Biology and Biochemistry. 24: 1317-1320. https://doi.org/10. 1016/0038-0717(92)90111-A.

Kalembasa D. 1996. The influence of vermicomposts on yield and chemical composition of tomato. Zesz Probl Post Nauk Roln. 437: 249-252.

Kaushik P, Garg VK. 2003. Vermicomposting of mixed solid textile mill sludge and cow dung with epigeic earthworm Eisenia fetida. Bioresource Technology, 90: 311-316. https://doi.org/10.1016/S0960-8524(03)00146-9.

Kolodziej M, Kostecka J. 1994. Some qualitative features of the cucumbers and carrots cultivated on the vermicompost. Zeszyty Naukowe Akademii Rolniczej W Krakowie. 292: 8994.

Lauritano C, Helland K, Riccio G, Andersen JH, Ianora A, Hanse, EH. 2020. Lysophosphatidylcholines and chlorophyllderived molecules from the diatom Cylindrotheca closterium with anti-inflammatory activity. Marine Drugs. 18: 166. doi:10.3390/md18030166.

Mitchell A. 1997. Production of Eisenia and vermicompost from feed-lot cattle manure. Soil Biology and Biochemistry. 29: 763-766. doi.org/10.1016/S0038-0717(96)00022-3.

Nardi S, Dell'Agnola G, Nuti PM. 1983. Humus production from farmyard wastes by vermicomposting. Proc. Int. Symp. On Agricultural and Environmental Prospects in Earthworm Farming. 87-94.

Pattnaik S, Reddy MV. 2012. Remediation of heavy metals from urban waste by vermicomposting using earthworms: Eudrilus eugeniae, Eisenia fetida and Perionyx excavatus. International Journal of Environment and Waste Management. 10(2): 284-296.

Riccio G, Lauritano C. 2020. Microalgae with immunomodulatory activities. Marine Drugs. 18: 2. doi:10.3390/md18010002.

Rosales-Mendoza S, Solís-Andrade KI, Márquez-Escobar VA, González-Ortega O, Bañuelos-Hernandez B. 2020. Current advances in the algae-made biopharmaceuticals field. Expert Opinion on Biological Therapy. 20: 751-766. doi: 10.1080/14712598.2020.1739643.

Sharma S, Pradhan K, Satya S, Vasudevan P. 2005. Potentiality of earthworms for waste management and in other uses - A Review. The Journal of American Science. 1: 4-16.

Shaymaa M, Ahmed H, Norli I, Morad N, Mahamad Hakimi I. 2010. Removal of Aluminium, Lead and Nickel from Industrial Sludge Via Vermicomposting Process. World Applied Sciences Journal,10(11): 1296-1305.

Shi-Wei Z, Fu-Zhen H. 1991. The nitrogen uptake efficiency from $15 \mathrm{~N}$ labeled chemical fertilizer in the presence of earthworm manure (cast) In: Veeresh GK, Rajagopal D, Viraktamath CA, editors. Advances in Management and Conservation of Soil Fauna. New Delhi: Oxford and IBH publishing Co; pp. 539-542.

Silva SC, Ferreira ICFR, Dias MM, Barreiro MF. 2020. Microalgae-Derived Pigments: A 10-Year Bibliometric Review and Industry and Market Trend Analysis. Molecules. 25: 3406. doi:10.3390/molecules25153406. 
Sinha RK, Herat S, Valani D, Chauhan K. 2009. Vermiculture and sustainable agriculture. American-Eurasian Journal of Agricultural and Environmental Sciences. IDOSI Publication. 5: 1-55.

Türkmen A, Kütük Y. 2017. Effects of Chemical Fertilizer, Algea Compost and Zeolite on Green Bean Yield. Turkish Journa of Agriculture-Food Science and Technology, 5(3): 289-293. https://doi.org/10.24925/turjaf.v5i3.289-293.977.
Türkmen M, Su A. 2019. The Effect of Sea Lettuce (Ulva lactuca) Liquid Fertilizer and Zeolite Combinations on the Development of Cucumber (Cucumis sativus). Turkish Journal of Agriculture-Food Science and Technology. 7(7): 10211027. https://doi.org/10.24925/turjaf.v7i7.1021-1027. 2520.

Türkmen M, Aydın T. 2021. Seasonal and Spatial Accumulation of Heavy Metals in Cystoseira barbata from Northeastern Black Sea Coasts. Indian Journal of Geo-Marine Sciences, 50 (4): 339-342.

Türkmen A, Akyurt İ. 2021. Mikroalglerin Antiviral Etkileri. Turkish Journal of Agriculture-Food Science and Technology. 9(2): 412-419. https://doi.org/10.24925/ turjaf.v9i2.412-419.4138. 